\title{
Deskripsi Sikap Siswa dalam Mata Pelajaran IPA di SMP IT Ashidiqi
}

\author{
Abu Ridlo ${ }^{1}$ \\ ${ }^{1}$ SMP IT Ashidiqi Batanghari, Jambi, Indonesia
}

\begin{tabular}{l}
\hline Article Info \\
\hline Article history: \\
Received Apr 1, 2020 \\
Revised Apr 14, 2020 \\
Accepted Apr 24, 2020 \\
\hline
\end{tabular}

\section{Keywords:}

Sikap

IPA

SMP

\begin{abstract}
ABSTRAK
Tujuan penelitian: Sikap merupakan hal yang penting dalam proses belajar dan pembelajaran. Sikap peserta didik sangat diperlukan karena sikap akan mempengaruhi hasil belajar peserta didik. Adapun Penelitian ini bertujuan untuk mengetahui deskripsi sikap terhadap penyelidikan dalam ipa, kesenangan dalam belajar ipa, dan ketertarikan memperbanyak waktu belajar ipa.
\end{abstract}

\begin{abstract}
Metodologi: Penelitian ini dilakukan di smpt it ashidiqi. Subjek penelitian sebanyak 75 siswa. Instrument yang digunakan adalah angket sikap peserta didik terhadap ipa yang berjumlah 7 indikator, akan tetapi peneliti hanya berfokus pada tiga indikator saja, yakni sikap penyellidikan dalam ipa, kesenangan dalam belajar ipa, dan ketertarikan menambah waktu belajar ipa. Teknik analisis data kuantitatif menggunakan statistik deskriptif.
\end{abstract}

Temuan utama: Hasil analisis yang diperoleh dari indikator sikap penyelidikan dalam ipa dengan kategori cukup baik yaitu $45.3 \%$ atau 34 dari 75 siswa. Kesenangan dalam belajar IPA dengan kategori baik yaitu 50.7\% atau 38 dari 75 siswa . Dan sikap memperbanyak waktu belajar ipa dengan hasil cukup baik yaitu $53.3 \%$ atau 40 dari 75 siswa.

Keterbaruan peneltian: Saat peserta didik memandang IPA secara positif, maka hal tersebut akan berdampak pada keberlangsungan proses belajar mengajar ipa didalam kelas yang dilakukan oleh guru dan peserta didik.

This is an open access article under the $\underline{C C B Y-N C}$ license

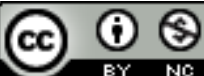

\section{Corresponding Author:}

Abu Ridlo

SMP IT Ashidiqi Batanghari, Jambi, Indonesia

email: aburidlo@gmail.com

\section{PENDAHULUAN}

Dalam memajukan kehidupan suatu bangsa, pendidikan memiliki peran utama. Dengan adanya pendidikan manusia dapat merubah pengetahuan serta tingkah lakunya menjadi lebih baik lagi [1]. mengertikan pendidikan sebagai upaya dalam meningkatkan kemampuan yang dimiliki oleh seseorang [2]. Pendidikan sebagai usaha secara sadar yang telah terencana untuk mewujudkan suasana belajar dan proses pembelajaran agar peserta didik mampu mengembangkan potensi yang ada pada dirinya [3].

Dalam pendidikan, terjadi yang namanya proses pembelajaran. Pembelajaran merupakan suatu proses untuk menghasilkan perubahan tingkah laku sebagai hasil dari adanya interaksi peserta didik dengan lingkungannya [4]. Pendidikan di indonesia memiliki beberapa tingkatan [5]. Salah satu tingkatan tersebut adalah sekolah menengah pertama (SMP). Sekolah menengah pertama merupakn jenjang yang wajib ditempuh sebelum melanjutkan ke tahap pendidikan yang lebih tinggi yakni sekolah menengah atas.

Yang menjadi patokan dalam keseluruhan dalam menilai apakah peserta didik mampu mengikuti pembelajaran adalah mata pelajaran IPA [6]. Ditingkat SMP, IPA memiliki banyak sekali kontribusi terutama menjadikan peserta didik menjadi generasi yang mempunyai sikap ilmiah. Sikap siswa itu penting, namun jauh dari itu semua guru juga memiliki peran penting dalam membentuk sikap peserta didik [7]. As is known if students have a positive attitude towards learning will have a major influence on learning [8]. Maksudnya yaitu peserta 
didik yang memiliki sikap positif akan mempengaruhi pada pembelajaran. Sikap yang dimiliki peserta didik akan berdampak pada proses serta hasil belajar peserta didik [9].

Untuk lebih melihat pandangan peserta didik terhadap IPA, dapat dilihat menggunakan indikator sikap, yakni sikap terhadap penyelidikan dalam ipa, kesenangan dalam belajar ipa, dan ketertarikan memperbanyak waktu belajar ipa. Pandangan tersebut dapat berupa pandangan positif dan negative. saat peserta didik memiliki kemauan untuk terus belajar IPA, maka peserta didik tersebut telah memandang IPA secara positif [10]. Pandangan yang positif terhadap IPA, akan memunculkan minat untuk melakukan penyelidikan dalam IPA, selain itu juga memunculkan kesenangan dalam belajar IPA, dan ketertarikan menambah waktu belajar IPA.

Penyelidikan ipa dapat membantu peserta didik dalam meningkatkan sikap serta keterampilan dalam penyelidikan ipa [6]. Beberapa hal yang dapat diselidiki dalam ipa adalah seperti penemuan - penemuan yang semakin berkembang. bahwa penyelidikan tersebut tidak hanya penemuan, namun juga dapat berupa eksperimen dalam melakukan percobaan [6].

Kesenangan dalam belajar IPA merupakan kecendrungan penilaian peserta didik terhadap mata pelajara IPA [11]. Saat peserta didik memiliki rasa senang dalam belajar IPA, maka peserta didik akan menambah waktunya dalam belajar IPA. Ketertarikan dapat diartikan sebagai ungkapan kesuakaan peserta didik dalam mempelajari IPA [5]. Ketertarikan menambah waktu belajar IPA akan berdampak pada banyaknya pengetahuan yang dimiliki oleh peserta didik. Ketertarikan menambah waktu belajar IPA apabila dilakukan secara opimal maka peserta didik akan menghasilkan hasil belajar yang baik [12]. Dalam proses pembelajaran, apabila peserta didik bersemangat maka dapat dikatakan bahwa peserta didik tersebut emiliki sikap positif, namun apa bila peserta didik acuh tak acuh maka ia memiliki sikap negative terhadap pelajarannya tersebut [13].

\section{METODE PENELITIAN}

Peneliti menghimpun fakta tentang sikap terhadap penyelidikan dalam ipa, kesenangan dalam belajar ipa, dan ketertarikan memperbanyak waktu belajar ipa. Sehingga diperoleh data kuantitatif yang perlu dianalisis untuk menghasilkan informasi.

Penelitian ini dilakukan di SMP IT Ashidiqi yang terletak di Jembatan Mas, Kec. Pemayung, Kab. Batanghari, Prov. Jambi. Adapun tujuan dilakukannya penelitian ini adalah untuk mendeskripsikan sikap terhadap penyelidikan dalam ipa, kesenangan dalam belajar ipa, dan ketertarikan memperbanyak waktu belajar ipa. Populasi dalam penelitian ini adalah seluruh siswa SMP IT ashidiqi yang berjumlah 75 orang, penelitian ini menggunakan teknik pengambilan sampel yaitu total sampling. Peneliti menggunakan total sampling karena peneliti ingin hasil penelitian berlaku untuk populasi yaitu siswa SMP IT ashidiqi.

Penelitian menggunakan instrumen penilaian tes berupa angket atau kuisioner. Angket penelitian ini diadopsi dari Astalini \& Kurniawan (2019) dengan nilai cronbach's alpha 0,842. Jenis angket yang peneliti gunakan adalah angket tertutup menggunakan skala likert. Instrumen tes ini menggunakan 5 poin skala likert. Skala yang digunakan pada instrumen angket sikap ini adalah skala likert lima poin yang terdiri dari STS "sangat tidak setuju”, TS “tidak setuju”, N "netral”, S “setuju”, dan SS “sangat setuju”[9]. Salah satu Instrumen sikap yang sering digunakan yaitu instrumen sikap TOSRA - Test of Science Related Attitudesyang dikembangkan oleh Fraser (1981) di negara Australia [14].

Dalam melakukan penelitian ini, langkah pertama yang dilakukan oleh peneliti adalah menyebarkan angket. Setelah menyebarkan angket, lalu akan didapatkan data. Dan data tersebut dianalisis menggunakan SPSS dengan analisis statistic deskriptif. secara umum statistic deskriptif digunakan untuk menggambarkan karakteristik data berupa rata-rata dan varisi data [15]. Indikator yang digunakan adalah sikap terhadap penyelidikan dalam ipa, kesenangan dalam belajar ipa, dan ketertarikan memperbanyak waktu belajar ipa.

\section{HASIL DAN PEMBAHASAN}

Keterbaharuan dari penelitian ini ialah indikator sikap terhadap mata pelajaran IPA yang digunakan yaitu sikap terhadap penyelidikan dalam ipa, kesenangan dalam belajar ipa, dan ketertarikan memperbanyak waktu belajar ipa yang di identifikasi pada siswa SMP IT ashidiqi jambi. Indikator ini diperoleh dari penelitian Fraser (1981) yang telah di implementasikan di Indonesia [16].

\subsection{Implikasi Sosial IPA}

Hasil analisis data statistic yang diperoleh peneliti dari siswa SMP IT ashidiqi mengenai indikator penyelidikan dalam IPA dapat dilihat pada tabel di bawah ini: 
Tabel 1. Hasil sikap penyelidikan dalam IPA

\begin{tabular}{ccccc}
\hline Variabel & Interval & Kategori Sikap & Frekuensi & $\begin{array}{c}\text { Persentase } \\
\%\end{array}$ \\
\hline & $7,0-12,6$ & Sangat Tidak Baik & 1 & 1,3 \\
Sikap & $12,7-18,1$ & Tidak Baik & 6 & 8,0 \\
Penyelidikan & $18,2-23,7$ & Cukup & 34 & 45,3 \\
dalam IPA & $23,8-29,3$ & Baik & 26 & 34,7 \\
& $29,4-35,0$ & Sangat Baik & 8 & 10,7 \\
\hline
\end{tabular}

SMP IT ashidiqi memiliki 75 orang peserta didik yang telah diteliti, berdasarkan hasil penelitian yang telah diolah menggunakan statistic desktriptif, peserta didik dikelompokkan kedalam 5 kategori. Pertama, kategori sangat tidak baik yang memiliki interval 7-12.6, pada kategori ini terdapat 1 peserta didik yang memiliki sikap tidak baik terhadap penyelidikan dalam IPA. Kedua, kategori tidak baik, dengan interval 12.7-18.1, pada kategori ini terdapat 6 peserta didik yang memiliki sikap tidak baik terhadap penyelidikan dalam IPA. Ketiga, kategori cukup baik dengan interval 18.2-23.7, pada kategori ini terdapat 34 peserta didik yang memiliki sikap cukup baik terhadap penyelidikan dalam IPA. Keempat, kategori baik dengan interval 23.8-29.3, pada kategori ini terdapat 26 peserta didik yang memiliki sikap baik dalam penyelidikan dalam IPA. Dan kelima, kategori sangat baik dengan interval 29.4-35, pada kategori ini terdapat 8 peserta didik yang telah memiliki sikap sangat baik dalam penyelidikan dalam IPA.

Rasa ingin tahu yang tinggi yang dimiliki oleh peserta didik menghantarkan peserta didik memiliki sikap penyelidikan yang tinggi. hal tersebut dapa dinilai pada saat melakukan eksperimen ataupun pemecahan masalah serta konsep konsep. Penyelidikan IPA akan membantu siswa meningkatkan sikap dan keterampilan penyelidikan terhadap IPA [6]. Saat peserta didik belum menemukan apa yang ia selidiki, maka secara tidak langsung, peserta didik tersebut akan menambah waktu mereka dalam belajar IPA. dan hal itu menandakan bahwa peserta didik menyenangi pelajaran ipa. Sikap penyelidikan dlam IPA yang dimiliki peserta didik dapat dilihat saat peserta didik pantang menyerah dalam melakukan eksperimen maupun dalam menyelesaikan soal soal yang diberikan oleh guru.

\subsection{Kesenangan dalam belajarn IPA}

Hasil analisis data statistic yang diperoleh peneliti dari siswa SMP IT ashidiqi mengenai indikator kesenangan dalam belajar IPA dapat dilihat pada tabel di bawah ini:

Tabel 2. Kesenangan dalam belajar IPA

\begin{tabular}{ccccc}
\hline Variabel & Interval & $\begin{array}{c}\text { Kategori } \\
\text { Sikap }\end{array}$ & Frekuensi & $\begin{array}{c}\text { Persentasi } \\
\%\end{array}$ \\
\hline & $9,0-16,2$ & Sangat Tidak Baik & 0 & 0 \\
Kesenangan dalam & $16,3-23,3$ & Tidak Baik & 1 & 1.3 \\
belajar IPA & $23,4-30,5$ & Cukup & 25 & 33.3 \\
& $30,6-37,8$ & Baik & 38 & 50.7 \\
& $37,9-45,0$ & Sangat Baik & 11 & 14.7 \\
\hline
\end{tabular}

Pada tabel 2 dapat dideskripsikan kesenangan dalam belajar ipa yang dimiliki oleh peserta didik SMP IT ashidiqi. Peserta didik dominan berkategori baik dengan interval 30.6-37.8 yaitu terdapat 50.7\% peserta didik atau 38 dari 75 responden berkategori baik dalam kesenangan dalam belajar IPA. 1.3\% siswa (1 dari 75) berkategori tidak baik. 33.3\% siswa (25 dari 75 siswa) berkategori cukup baik. Dan sisanya 14.7\% (11 dari 75 siswa) berkategori sangat baik.

Hal ini menunjukkan bahwa siswa memiliki sikap baik dalam kesenangan belajaar IPA. sikap kesenangan dalam belajar ditentukan oleh suasana serta cara belajar peserta didik[17]. Kesenangan belajar bergantung pada proses belajar mengajar, peserta didik senang belajar akan berdampak positif terhadap guru [18]. siswa di kategorikan baik diketahui siswa suka belajar ipa, misalnya siswa di dalam kelas aktif bertanya dan berani menyampaikan jawaban didepan kelas saat proses belajar mengajar.

Rasa senang yang dimiliki peserta didik dapat dipengaruhi oleh guru mata pelajaran itu sendiri. saat guru menjelaskan materi dengan baik dan rinci serta mampu menarik minat peserta didik, maka peserta didik akan menyukai pelajaran tersebut yakni ipa. namun sebaliknya saat guru tidak pandai dalam menarik minat peserta didik, maka peserta didik tidak memiliki rasa senang dalam mempelajari ipa. Peserta didik yang memiliki rasa senang, kan menambah waktunya untuk belajar ipa dan menyelidiki ipa lebih dalam lagi, seperti belajar sendiri dirumah, mengikuti les atau privat tambahan, ataupun belajar berkelompk bersama teman-temannya. Hal tersebut dilakukan peserta didik, karena ia memandang ipa secara positif. 


\subsection{Ketertarikan memperbanyak waktu belajar IPA}

Hasil analisis data statistic yang diperoleh peneliti dari siswa SMP IT ashidiqi mengenai indikator ketertarikan memperbanyak waktu belajar IPA dapat dilihat pada tabel di bawah ini:

Tabel 3. Data ketertariakan memperbanyak waktu belajar IPA

\begin{tabular}{ccccc}
\hline Variabel & Interval & $\begin{array}{c}\text { Kategori } \\
\text { Sikap }\end{array}$ & Frekuensi & $\begin{array}{c}\text { Persentasi } \\
\%\end{array}$ \\
\hline Ketertarikan & $8,0-14,4$ & Sangat Tidak Baik & 0 & 0,0 \\
meluangkan belajar & $14,5-20,7$ & Tidak Baik & 6 & 8,0 \\
IPA & $20,8-27,1$ & Cukup & 40 & 53,3 \\
& $27,2-33,5$ & Baik & 22 & 29,3 \\
& $33,6-40,0$ & Sangat Baik & 7 & 9,3 \\
\hline
\end{tabular}

Pada tabel 3. Dideskripsikan sikap ketertarikan belajar IPA yang dimiliki oleh siswa SMP IT ashidiqi. Pada tabel dapat kita lihat bahwa peserta didik dominnan berkategori cukup baik yaitu 53.3\% (40 dari 75 siswa). 29.3\% berkategori baik (22 dari 75 siswa) dan untuk kategori sangat baik yaitu 9.3\% (7 dari 75 siswa). Tidak terdapat peserta didik yang memiliki sikap sngat tidak baik untuk ketertarikan memperbanyak waktu belajar IPA.

Hasil tersebut menunjukkan bahwa siswa smp it ashidiqi meluangkan waktu yang banyak untuk beljar ipa. ada beberapa alasan peserta didik meluangkan waktu untuk belajar opa, diantaranya rasa penasaran yang tinggi akan hal baru. Peserta didik yang memperbanyak waktu mereka dalam mempelajari ipa ialah peserta didik yang memandang IPA secara positif. Rasa ketertarikan untuk menambah waktu belajar ipa yang dimiliki peserta didik dapat dilihat saat peserta didik menyelesaikan semua tugas yang diberikan, selain itu peserta didik juga mengikuti les atau privat diluar jam sekolah $[19,20]$. Tidak hanya itu, peserta didik juga meluangkan waktunya untuk mengulang kembalai pelajarannya di rumah setelah belajar disekolah.

Ketertarikan memperbanyak waktu belajar ipa yang dimiliki peserta didik akan mepengaruhi hasil belajar peserta didik. Peserta didik yang memperbanyak waktunya dalam belajar ipa akan lebih memahami materi pelajaran karena ia mengulang kembali apa yang telah ia pelajari sebelumnya disekolah. Berbeda dengan peserta didik yang tidak tertarik untuk memperbanyak waktu belajar ipa, ia akan cendrung memiliki hasil belajar yang tidak baik, secara tidak langsung, peserta didik tersebut telah memandang ipa secara negative [21, 22]

\section{KESIMPULAN}

Berdasarkan hasil analisis yang didapatkan, sikap peserta didik ditiap indikator di SMP IT ashidiqi tidak berbeda jauh. Hal ini dapat dinilai dari guru pengampu bidang studi yang ada di sekolah, bagaimana cara guru dalam menanamkan konsep kepada siswa agar tidak memiliki anggapan bahwa ipa adalah pelajaran yang sulit. Siswa yang memandang ipa secara positif akan senang mempelajari IPA, kemudian ia akan memperbanyak waktunya dalam belajar IPA, serta memiliki sikap penyelidikan dalam IPA yang baik. Hasil menunjukkan bahwa $45.3 \%$ peserta didik memiliki sikap penyelidikan dalam ipa yang cukup baik, $50.7 \%$ siswa memiliki rasa senang yang baik terhadap IPA, dan 53.3\% siswa memiliki rasa ketertarikan belajar ipa yang cukup baik.

\section{UCAPAN TERIMA KASIH}

Peneliti mengucapkan terimakasih kepada seluruh responden yang telah bersedia dan seluruh elemen yang telah membatu, saya ucapkan terimakasih.

\section{REFERENSI}

[1] A. Astalini, D.A Kurniawan, R. Perdana, and W. Kurniawan, "Identification Attitudes of Learners on Physics Subjects," Journal of Educational Science and Technology, vol.5, no.1, pp.39-48, 2019.

[2] B. Raharjo, "Pendidikan Karakter Sebagai Upaya Menciptakan Akhlak Mulia". Jurnal Pendidikan Dan Kebudayaan, vol 3, pp 229-238. 2010

[3] Undang undang republik Indonesia nomor 20 tahun 2003

[4] Muhamad Surya. "Psikologi Pembelajaran dan Pengajaran". Bandung: Pustaka Bani Quraisyi. 2004

[5] D. S. Putra., A. Lumbantoruan., and S. C. Samosir, "Deskripsi sikap siswa: adopsi sikap ilmiah, ketertarikan memperbanyak waktu belajar fisika dan ketertarikan berkarir dibidang fisika". Tarbiyah: Jurnal Ilmiah Kependidikan, no. 8. Vol.2 pp 91-100. 2019

[6] Astalini, D.A Kurniawan, R. Melsayanti, and A. Destianti, "Sikap Terhadap Mata Pelajaran IPA di SMP Se-Kabupaten Muaro Jambi,” Lentera Pendidikan, vol. 21,no.2, pp. 214-227, 2018. 
[7] Hidayati, Astalini., dan D. A. Kurniawan, "Pengembangan Inovasi Pembelajaran Berbasis Proyek Ilmiah dalam Meningkatkan Sikap terhadap Ilmu Pengetahuan Siswa SMP Kota Malang” Jurnal Konseling dan Pendidikan, vol. 5, no. 2, pp. 85-91, 2017.

[8] A. Astalini, D.A Kurniawan, R. Perdana, and W. Kurniawan, "Identification Attitudes of Learners on Physics Subjects," Journal of Educational Science and Technology, vol.5, no.1, pp.39-48, 2019.

[9] Astalini, D.A. Kurniawan, and A.D. Putri, "Identifikasi Sikap Implikasi Sosial dari IPA, Ketertarikan Menambah Waktu Belajar IPA, Dan Ketertarikan Berkarir di bidang IPA Siswa SMP Se-Kabupaten Muaro Jambi,’Jurnal Tarbiyah: Jurnal Ilmiah Kependidikan, vol.7, no.2, pp.93-108, 2018.

[10] G. Hamdu, and L. Agustina,. "Pengaruh motivasi belajar siswa terhadap prestasi belajar IPA di sekolah dasar". Jurnal penelitian pendidikan, no.12. vol.1, pp. 90-96. 2011

[11] D.A Kurniawan,., Astalini, A., and Kurniawan, N.” Analisis sikap siswa terhadap ipa di smp kabupaten muaro jambi provinsi jambi". Curricula: Journal of Teaching and Learning, no.4. vol.3, pp. 111-127. 2019

[12] A. Lumbantoruan, and N. Jannah, "Sikap Siswa pada Pelajaran Fisika: Adopsi Sikap Ilmiah, Kesenangan Belajar, dan Ketertarikan Menambah Waktu Belajar”. SPEKTRA: Jurnal Kajian Pendidikan Sains, no.5. vol.2, pp.161-172. 2019

[13] Maison., Astalini., D. A. Kurniawan., R. Perdana., L. Anggraini, "The Phenomenon of Physicology Senior High School Education: Relationship of Students' Attitudes towards Physics, Learning Style, Motivation. Universal Journal of Educational Research. vol. 7, no. 10, pp. 2199-2207, 2019,

[14] D. A. Kurniawan., Asrial., Syahrial., W. S. Salsabila., E. F. Kurniawati., Q. S. Anandari., R. Perdana., A. Lumbantoruan., N. Nasih., S. C. Samosir., U. P. Dewi, "Etnoscience Investigation in Pimary Schools: Impact on Science Learning", Universal Journal of Educational Research, vol. 7, no. 12, pp. 2789-2795. 2019.

[15] Syahrial., Asrial., D. A. Kurniawan., P. Nugroho., R. Septiasari., R. A. Pratama., dan R. Perdana, "Increased Behavior of Students' Attitudes to Cultural Values using the Inquiry Learning Model Assisted by Ethnoconstructivism”. Journal of Educational Science and Technology, vol. 5, no. 2, pp. 176-188. 2019

[16] Maison., Darmaji., Astalini., D. A. Kurniawan., Sumaryanti., dan R. Perdana, "Supporting Assessment in Education: EAssessment Interest in Physics", Universal Journal of Education Research, vol. 8, no. 1, pp. 89-97, 2020.

[17] R. S. Budiarti., Harlis., D. Natalia, "High Oder Thinking Skills for Biology Education: Applied Microbiology Learning Videos Based on Jambi Local Wisdom”, Universal Journal of Education Resaerch, vol. 8, no. 2, pp. 689-694. 2020

[18] Astalini., D. A. Kurniawan., L. Anggraini, "Correlation between confidence with attitude toward science in secondary school in Indonesia”. Beder Scientific Journal of Education Sciences (BJES), vol. 20, no. 1, pp. 30-45, 2019

[19] R. Rahmayeni, "Kerja keras siswa dalam pelajaran sains”, Journal Evaluation in Education, vol. 1, no. 1, pp. 27-33, 2020

[20] M. Corry, "Identifikasi religiusitas siswa di sma adhyaksa 1 jambi", Journal Evaluation in Education, vol. 1, no. 1, pp. $15-20,2020$

[21] N. Neldawati, "Deskripsi lingkungan belajar siswa terhadap mata pelajaran fisika di sma ferdy ferry putra kota jambi”, Journal Evaluation in Education, vol. 1, no. 1, pp 1-7, 2020

[22] S. Hasrani, "Kreativitas siswa dalam mata pelajaran ipa", Journal Evaluation in Education, vol. 1, no. 1, pp. 21-26, 2020 